\title{
Tumor Margin Configuration
}

National Cancer Institute

\section{Source}

National Cancer Institute. Tumor Margin Configuration. NCI Thesaurus. Code C137709.

Describes the morphologic appearance where a tumor meets the adjacent tissue. 